\title{
Substance Use Group Identifier
}

National Cancer Institute

\section{Source}

National Cancer Institute. Substance Use Group Identifier. NCI Thesaurus. Code C83422.

A character or string that represents a substance usage group. 